\title{
LHC and space station get funding strings
}

[WASHINGTON] A committee of the US House of Representatives gave backhanded endorsements to two controversial international programmes last week, authorizing US funding for both the International Space Station and the Large Hadron Collider (LHC) at the European Laboratory for Particle Physics (CERN) in Geneva, Switzerland, but in each case attaching conditions to its approval.

The endorsements are not definitive, as a Senate committee must also have its say along with appropriations committees in both houses. But they do provide an indication of policy direction. In particular, the LHC vote represents defeat for a bid to cut funding completely, but still reflects congressional caution.

The committee voted unanimously to require the National Aeronautics and Space Administration (NASA) to meet strict requirements if Russian participation in the space station is to continue. In an amendment to a bill authorizing spending on civilian space science in 1998 and 1999, the committee barred NASA from transferring money to Russia or its contractors for work on the space station that the Russians have pledged to finance.

The amendment also requires NASA to certify each month whether or not the Russians are on schedule with their obligations to provide promised hardware, and to detail contingency plans where they fail. It requires President Bill Clinton to tell Congress by the beginning of August whether Russia's promised hardware will be in place for the service module launch date of December 1998. And it forbids US astronauts from long-term stays on the Russian Mir spacecraft until NASA certifies that it meets US safety standards.

The amendment was jointly sponsored by James Sensenbrenner Jr (Republican, Wisconsin), the committee chairman, and George Brown (Democrat, California), the senior Democrat on the committee. Sensenbrenner made it clear that his continued support for the space station was granted reluctantly, arguing that NASA and the White House were in "denial" about Russia's ability to meet its obligations.

"There will be opportunities yet to remove the Russians from the programme if the station is not put onto a better track," he said, but added that such a decision would at present be "premature". Meanwhile, he called the amendment "an appropriate and measured step".

Funding for the LHC survived by eight votes an attempt to kill it by Joe Barton (Republican, Texas), who described the acronym as standing more appropriately for "Let's Have [US] Cash". Barton said he was opposed to "paying ransom for our scientists to participate" in the LHC, recall- ing what he termed the European failure to support the ill-fated Superconducting Super Collider, which was to have been built in Texas.

The Department of Energy had asked for $\$ 450$ million - $\$ 100$ million of it in 1998 and 1999 - to help Europe build the LHC, which is due for completion in 2005. Instead, the committee stipulated that none of the funding for US high-energy physics should be used for the LHC unless the Secretary of Energy had reported to the committee and its Senate counterpart on the impact of US support for the LHC "on the operations and viability of United States high-energy and nuclear physics facilities". Sensennbrenner is to visit CERN this week.

In a separate vote, the committee voted by 18 to 8 to eliminate a $\$ 10$-million increase in the \$131-million budget for the Stanford Linear Accelerator Center. Vern Ehlers (Republican, Michigan), a physicist by training, sponsored the amendment cutting the money, arguing that such earmarking for specific facilities were inappropriate.

Overall, the committee approved bills that increased 1998 funding for the National Science Foundation by 7.2 per cent over 1997 - slightly more than the 7 per cent that science lobbyists had been seeking (see Nature 385,$103 ; 1997$ ) — to $\$ 3.5$ billion.

Meredith Wadman

\section{Creationist 'Ark' trial closes early after judge narrows focus}

[SYDNEY] Australia's creationist trial ended earlier than anticipated last week after its scope, expected to encompass science education and the relationship between science and religion, had been considerably narrowed by Judge Ronald Sackville.

Sackville ruled as irrelevant much of the affidavits of two potential witnesses, Eugenie Scott of the US National Center for Science Education, and Edwin Byford, an Anglican theologian from Broken Hill, New South Wales. Neither was called to give verbal evidence on behalf of Ian Plimer, a geologist at the University of Melbourne.

Plimer has been challenging claims made in 1992 by Allen Roberts, an 'archaeological consultant' from Sydney, to have found "scientific evidence" for the remains of Noah's Ark at Akyayla in eastern Turkey (see Nature 386,638 ; 1997)

Cross-examined by Plimer's barrister, Stephen Walmsley, Roberts distanced himself from Ark Search, the association that has promoted Roberts's lectures and sold tapes and brochures bearing his copyright. Linking Roberts with trade or commerce has been crucial to Plimer's allegations that Roberts and Ark Search engaged in misleading and deceptive conduct.

Roberts holds a doctorate in Christian education from a peripatetic Bible college in Florida. Plimer's team argued that Roberts lacked the qualifications to conduct scientific tests for evidence of 'a great boat' and its human and animal passengers, and indeed had not carried out any tests.

Roberts admitted, in a written response to questions, that his claims to this effect were incorrect. He explained that when he had said during his lectures that "we found" fossilized remains he was referring not to himself but to a "fraternity" of Ark searchers. This group included two Americans, his supporter, Ron Wyatt of Nashville, Tennessee, and his opponent David Fasold.

Fasold, a former marine salvager from Oregon, is alleging that Roberts had breached his copyright in publishing a drawing of the 'Ark'. But this was denied by the artist Bruce Midgley, who had drawn a similar diagram for Roberts' brochure. Fasold is seeking financial damages.

Plimer is hoping that the judge will grant an injunction restraining Roberts from any further commercialization of his claims. Plimer believes such an order would act as a

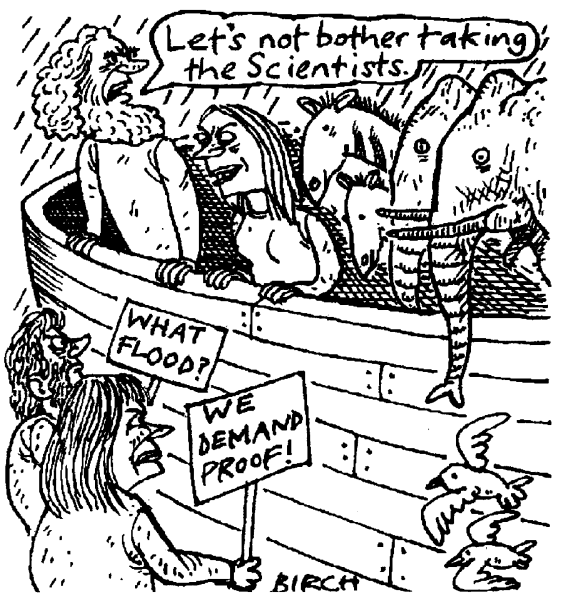

deterrent to the efforts of fundamentalists to have 'creation science' taught alongside evolution in schools.

But Sackville expressed doubts about the use of the courts to adjudicate between competing ideas. "We have schools in this country that teach creation science or whatever," he said. "Are we going to protect all children from hearing these ideas, however ill-conceived Professor Plimer and others may think they are?"'This verdict is expected in a few weeks.

Peter Pockley 